\title{
OBITUARIES
}

\section{MARCEL COHEN}

The death of Marcel Cohen on 5 November 1974 was a grievous loss to linguistic scholarship, and to the study of Hamito-Semitic, above all of Ethiopian languages. Indeed, Hamito-Semitic studies owe to him their 'ennoblement' during the first half of this century. In Ethiopian studies Marcel Cohen acquired a pre-eminent position and became one of our masters along with Ludolf and Dillmann, Praetorius, Mittwoch and Littmann, Guidi and Conti Rossini, who had preceded him since the seventeenth century.

Marcel Cohen was born in Paris on 6 February 1884. He studied and obtained his baccalauréat at the Lycée Condorcet. He attended A. Meillet's lectures at the Collège de France and the Ecole des Hautes Etudes. ${ }^{1}$ Meillet discovered in the young linguist a scholar with an acute mind. He introduced him to comparative Indo-European linguistics and encouraged him to devote himself to Semitic languages. In 1905 Marcel Cohen registered at the École des Langues orientales. ${ }^{2}$ for spoken Arabic (arabe vulgaire) and graduated in 1909. He also read Amharic there under C. Mondon-Vidailhet. At the same time he studied French linguistics with F. Brunot at the Sorbonne and with Mario Roques at the Hautes Etudes, Sanskrit with Sylvain Lévi, and Ethiopic and South Arabian with Joseph Halévy. Marcel Cohen decided to write his thesis at the École des Hautes Etudes on a subject in the field of Arabic dialectology. He travelled to Algeria two or three times in 1908 and 1909 and shortly afterwards (1909) he submitted Le parler arabe des juifs d'Alger (Paris, Champion, 1912). This thesis won him the Prix Volnay for 1912.

In Algiers he met W. Marçais, then Director of the Médersa, who proposed that together they should translate into French C. Brockelmann's Semitische Sprachwissenschaft. That translation was published two years later (Précis de linguistique sémitique, Paris, Geuthner, 1910).

All these works and studies did not prevent Marcel Cohen from taking the very French (and very difficult) examination leading to an official university career : in 1908 he became Agrégé de l'Université. At the end of 1909 he spent several months at the University of Berlin. There he made contact with Semitic scholars and with linguists.

From March 1910 to June 1911 he was enabled by the Ministry of Education to undertake a journey in Ethiopia. This mission was decisive for his future. It is difficult to describe how well he turned to account his stay in the country. Even his report (Rapport sur une mission linguistique en Abyssinie 1910-1911,

1 EPHE-Ecole pratique des Hautes Études, called also École des Hautes Études or simply Hautes Etudes. All references here are to the IVth Section of that Sohool (Section des sciences historiques et philologiques).

2 ELOV-Ecole des Langues orientales vivantes; since 1914-École nationale des Langues orientales vivantes.

voL. XXXVIII. PART 3. 
Paris, 1912) does not give an appropriate idea of all his achievements. It may be enough to point out that the linguistic material he collected at that time gave him work for many years and enabled him to advance Ethiopian linguistics considerably.

Back in Paris he was appointed lecturer (chargé de cours) in Amharic at the Ecole des Langues orientales vivantes (assistant Professor 1916; full Professor 1926), a post he bequeathed to his student J. Tubiana on his retirement in 1950. In 1919 Marcel Cohen also became professor (directeur d'études) of Ethiopic (later also of South Arabian) at the Ecole pratique des Hautes Etudes. He taught there until 1967, although since $1955 \mathrm{M}$. Rodinson, another of his students, had taken over the main part of the teaching as a new directeur d'études of the same subjects.

Marcel Cohen had an incredibly wide range of scholarly interests. His main fields of study were Ethiopian languages, comparative Semitics, and HamitoSemitic linguistics. Although after his research journey in 1910-11, he never returned to Ethiopia (except for a few days in 1964), he wrote dozens of articles and notes on different subjects connected with most of the Semitic languages of Ethiopia. His main contributions in that field concern the South Ethiopian languages and Ethiopic (Ge'ez). Three books must be enumerated first. In Études d'éthiopien méridional (Paris, Geuthner, 1931) he described the dialectal distribution of the Ethiopian languages, analysed the main phonetic problems of the South Ethiopian area, and gave a description of Gurage, Harari, and Argobba. Next he published the Traité de langue amharique (Paris, Institut d'Ethnographie, 1936 ; second edition, 1970) which remains even now the best manual of Amharic (though it describes the language of the first quarter of this century). In order to give the student a clear image of Amharic, Marcel Cohen left aside all the detailed and more complicated questions and published them almost simultaneously in a separate volume, Nouvelles études d'éthiopien méridional (Paris, Champion, 1939) with cross-references to the Traité. He also added to the Amharic part of that book another one, dealing with South Argobba.

Ethiopic was, like Amharic, one of Marcel Cohen's main fields of interest. The originality of his research and of his teaching of Ge'ez consisted in the fact that he used to base them on traditional Ethiopian linguistic teaching. This concerned not only the traditional pronunciation (" La prononciation traditionnelle du guèze', $J A$, xI ${ }^{\mathrm{e}}$ Ser., xvIII, oct.-déc. 1921, 216-69) which had been described independently by two other great éthiopisants before him (Littmann, 1917-18) and after him (Mittwoch, 1925) but also other aspects of linguistics, including the grammatical and especially the syntactical nomenclature. See the French translation (jointly with R. Schneider) of Abbä Takla Māryām Walda Samhārāy's grammar, chapter iii ( $R S E$, xIIr, 1954, and XIV, 1955-8).

During his long years of teaching Ge'ez he also prepared a typewritten grammar (Esquisse d'une étude de la langue guèze) a copy of which is to be found at the École des Hautes Études. Among his unpublished material there are also 
supplements to the dictionaries of $\mathrm{Ge}^{6} \mathrm{ez}$ (about 400 cards) and of Amharic (about 5,000 cards).

Marcel Cohen was a linguist with a profound interest in ethnography and in sociology. In the Ethiopian field that interested was expressed in numerous articles concerning the material culture, games, ceremonies, popular beliefs and magic, music and poetry, social life and political situation. During the ItaloEthiopian war he was among the active defenders of Ethiopia's independence and published articles on the country and its institutions. From his journey in 1910-11 he also brought a rich documentation which he used in many papers; two collections of them were also issued in separate volumes, Documents ethnographiques d'Abyssinie (Paris, Leroux, 1920) published first in REES, and Couplets amhariques du Choa (Paris, Imprimerie Nationale, 1924) published in $J A$. The latter was submitted by Marcel Cohen as a complementary doctoral thesis in the same year.

Among the other Semitic languages another of his great interests was South Arabian. From 1927 he supervised the printing of CIS, Pars IV, Tom. III, 'inscriptiones himyariticas et sabaeas continens' (Paris, 1929, but printed between 1929 and 1931) prepared by Mayer Lambert with Cohen's additions. Later he also published Documents sudarabiques (Paris, dépôt chez Adrien Maisonneuve, 1934).

Following A. Meillet's advice, Marcel Cohen devoted himself to comparative Semitics. His main contribution in that field, Le système verbal sémitique et l'expression du temps (Paris, Leroux, 1924) became his principal doctoral thesis and was awarded the Prix Volnay for 1924. This work marks a milestone in the study of the Semitic verb. Another work which must be cited here is 'Verbes déponents internes (ou verbes adhérents) en sémitique' (MSL, xxIIr, 4, 1929, 225-48). Here he introduced for the first time the notion of 'internal deponents" into the study of Semitic languages. This morphological category was investigated many years later by him and his students in more detail in Ethiopic.

However, the comparative study of Semitic languages led him very early to consider the larger linguistic family of which they constitute a part. In the monumental review of all known languages, Les langues du monde (Paris, Champion, 1924), a collective work initiated by Meillet and edited by him and by Marcel Cohen, for the first time in history the Hamito-Semitic languages were described as a coherent family with a well-defined linguistic system (" Langues chamito-sémitiques', ibid., 81-181). The second edition of this book, completely revised, was edited by Marcel Cohen alone in 1952, although the names of both the original editors were preserved.

Marcel Cohen struggled all his life for the recognition of the Hamito-Semitic family and for an intensive study of it. In 1931 he organized in Paris an international learned society called Groupe Linguistique d'Etudes ChamitoSémitiques (GLECS) devoted to that subject. The Comptes rendus du GLECS, which still appear, played and are still playing an important role and are a link between more than 100 scholars from about 20 countries. Marcel Cohen 
devoted a part of his teaching to the Hamito-Semitic family. His lectures on that subject delivered between 1911 and 1915 at the ELOV were a prelude to his chapter in the Langues du monde. Between 1932 and 1940 a part of his lectures and seminars at the EPHE dealt with the analysis of the comparative vocabulary, while he had been preparing his opus magnum in that field, the Essai comparatif sur le vocabulaire et la phonétique du chamito-sémitique, published only after the second World War (Paris, Champion, 1947 ; second edition, 1969). Morphological unity having been previously established, he decided to compare the vocabularies of the Hamito-Semitic languages. He first compiled for that purpose a list of words in French belonging to the 'fundamental vocabulary' and then checked the corresponding words in the different languages investigated. That gave him nearly 500 entries. The inquiry covered four branches: Semitic, Egyptian, Lybico-Berber, and Cushitic. Hausa, of which examples were quoted, was not included in Hamito-Semitic. This comparative study enabled the author to establish for the first time phonetic equivalences between the branches of the Hamito-Semitic domain. The book evoked criticism (among the opponents was C. Brockelmann) and discussion which led finally to an almost general recognition of the Hamito-Semitic family. Discussion also concerned the name to be given to it ('Afro-Asiatic' has since been proposed by Joseph H. Greenberg and 'Erythraic' by A. N. Tucker) as well as its extension, namely the possible inclusion of a fifth wide group of languages, the Chadic, to which Hausa belongs.

We may say in this connexion that the comparative study of the HamitoSemitic vocabulary in its historical and social environment combined with his deep knowledge of Indo-European linguistics led Marcel Cohen to the investigation of 'mots voyageurs', especially of those belonging to the Mediterranean area. He wrote almost 20 articles about them.

He had the satisfaction of attending the first International Congress of Hamito-Semitic Linguistics (Paris, 1969) and the subsequent Hamito-Semitic International Conference (London, 1970) but his deteriorating health prevented him from attending the second International Congress (Florence, 1974), just a few months before his death.

Marcel Cohen early became fascinated by writing, its techniques and its evolution. He wrote articles and took part in discussions on questions of transliteration and transcription, and on the relationship between language and writing. He had the idea of including language and writing in the Palais de la Découverte in Paris (1948). He helped in organizing special rooms for displaying them as two main human inventions. As early as in 1936 he conceived the idea of a book about the history of writing considered as an invention but it was only during the war that the first draft of it was written. In 1958 appeared $L a$ grande invention de l'écriture et son évolution (Paris, Klincksieck) in three large volumes: text, documentation, and plates. Although the history of writing is familiar to Orientalists and in spite of the fact that several books were published on that subject in the late 1940's and in the 1950's, Cohen's work is new in many 
respects. The author emphasizes the successive inventions applied to writing, the means of adapting writing to languages, the tracings (" les tracés ') including transformation of the alphabet (e.g. secret scripts, shorthand, alphabets for deaf-mutes, for the blind, etc.), the notation of numbers, of music and dance. A special chapter deals with writing and industrial tools (reproduction and transformation of writing). A useful systematic summary is given at the end, presented as a 'formulaire d'essai pour une étude scientifique de l'écriture'. One can also gain an idea of Marcel Cohen's extraordinary competence in that field by reading the papers presented at the XXIInd 'Semaine de Synthèse' organized by the Centre International de Synthèse on the subject L'écriture et la psychologie des peuples (Paris, Armand Colin, 1963) and the discussion which followed. He was not only the principal consultant of that symposium but dominated the whole discussion.

I cannot describe here in detail all the other fields of his scholarly activity. His interest in general linguistics and linguistic methods was always very strong. He was a Marxist and tried to apply dialectic materialism to linguistics. One must emphasize in this context that he never accepted Marr's linguistic theory even when it became compulsory in the Communist world; his refusal was obviously possible only because he was living in the West.

The main characteristic of his approach toward language was his ability to discover and analyse the social functions of linguistic factors. In 1948 and 1949 Marcel Cohen delivered a series of lectures at the Centre d'Études Sociologiques. Edited in mimeographed form those lectures, Initiation aux recherches sur Société et langage (1948) and Société et langage. I1. Autour du vocabulaire (1949), formulate a series of questions to which many others have been added later. All this was reconsidered by Marcel Cohen who a few years later made a very successful 'attempt' - as he called it himself-' to assemble certain data and to investigate how to search for others in order to multiply the approaches and not to leave aside anything important in the relation between language and society'. Enriched by important documentation the new work, Pour une sociologie du langage, went through two editions (Paris, Albin Michel, 1956; Maspero, 1971). The second edition was published in two volumes under a slightly modified title, Matériaux pour une sociologie du langage. The broad range of ideas and the documentation make that book indispensable for both linguists and sociologists.

From his first field-work Marcel Cohen proved his ability in linguistic investigation. In 1926 he was invited to teach descriptive linguistics at the newly organized Institut d'Ethnologie, Universite de Paris. As a result of that teaching he published in 1928 both the Instructions d'enquête linguistique and the two volumes of the Questionnaire linguistique (second edition, 1951).

This meticulous observer, sensitive to the whole linguistic environment, social and ethnographic, gave us a series of studies important for what we now call sociolinguistics. His very first article (MSL, xv, 3, 1908-9, 170-92), was 'Le langage de l'École Polytechnique', and may be the most complete study of 
the slang of a particular school. It was the observation of the language used by his brother André, who graduated from that school in 1906, which drew his attention to the problem of slang. That interest never vanished in Marcel Cohen.

Another subject on the border of general linguistics and sociology which attracted him was children's language. Not only did he carefully note the evolution of his own children's language and published different papers on this question from 1922, but he remained attached to it all his life. He published a documented study, 'Sur l'étude du langage enfantin', Enfance, v, 3, 1952, 181-249, his last contribution appeared in Études sur le langage de l'enfant (Paris, Éditions du Scarabée, 1962).

Because of his genuine linguistic curiosity Marcel Cohen showed a profound interest in his mother tongue, French. That interest grew with time, especially after the second World War. Among the many books he wrote let us mention probably the most important, finished about 1939 but published only in 1947, Histoire d'une langue: le français (Paris, Editeurs Réunis; fourth edition, Editions Sociales, 1974). Marcel Cohen also undertook to publish (together with Maurice Davau and Maurice Lallemand) an entirely new French dictionary on which he worked for more than 20 years, Dictionnaire du français vivant (Bordas, 1972), usually called 'Dictionnaire Bordas'. Hundreds of articles concerning modern French have been published by him in non-academic newspapers and reviews. Most of them have been collected in volumes: Regards sur la langue française (Paris, Éditions Sociales, 1950), Grammaire et style (1954), Nouveaux regards sur la langue française (1963), Encore des regards sur la langue française (1963), and Une fois de plus des regards sur la langue française (1972).

Marcel Cohen had a gift of explaining complicated matters in an easy and clear manner. That gift of popularization was used by him not only in the field of French but also in presenting problems of a more general character. $\mathrm{He}$ published a valuable book of that kind concerning language, Le langage, structure et évolution (Paris, Editions Sociales, 1950) later translated into Polish, English, Japanese, and Chinese. Another book in the same series concerned writing, L'écriture (1953), and was a by-product of the monumental La grande invention de l'écriture.

All his life he was an indefatigable reader and reviewer. Many of his reviews were important contributions and it is impossible not to take them into account when describing the scholar. He wrote about 1,700 reviews of books and periodical publications. Thus, from 1907 to 1962 he published in the Bulletin de la Société de Linguistique de Paris about 890 reviews and from 1949 to 1972 (published 1973) about 740 reviews in Année Sociologique.

He was a good university teacher, perhaps less a teacher and more a directeur d'études. Almost all the students who attended his course of Amharic at the ELOV at a certain stage joined his seminar at the EPHE at which he used to introduce members to research work. Very exacting, he not only required a systematic account of the work carried out by students preparing a thesis or any 
other research, but he guided the students, mainly by putting questions, by presenting new problems, by asking for more inquiries. His personal example was inspiring and many subjects later described by his students resulted from questions put before them by the Master. He always carried dozens of cards or small slips of paper in his brief-case with questions he had to ask his pupils and with answers he brought on questions he had been asked a week or a month before. That exchange of information was one of the main features of his working with people. He always attracted a great number of students, not only éthiopisants or Semitic scholars but also linguists, ethnographers, sociologists, even technicians and scientists, as he was curious about technological and scientific progress.

Ethiopian informants were of special importance to him. Many Ethiopians staying in Paris or travelling to France used to come and see him, to pay him a visit at his home, and he always had questions to ask them. Among the guests there were often prominent officials and even members of the imperial family. His house in Viroflay was an open one for his students and friends. He was always helpful with his students, respected by them, although in some of them he inspired respect mixed with a certain fear. I do not remember which of his students first called him 'le Bon Maitre' but this nickname remained and is still used among us. That kind of reciprocal loyalty was a rule to which I know of very few exceptions.

Marcel Cohen's career, as happens so often, did not develop entirely according to his abilities and to his expectations. From 1911 to 1950 his main burden was the almost uninterrupted teaching of Amharic at the ELOV. Only for two years (1937-8 and 1938-9) did he obtain leave of absence for research purposes. The two main interruptions in his teaching correspond to the two World Wars. During the first he was in the forces and won the Croix de Guerre and the Légion d'Honneur. During the second war, after the armistice, he was dismissed from his posts ex officio, because of the racist laws of the occupied country. Marcel Griaule, one of his most gifted students whom he had helped on many important occasions, then accepted his place at the ELOV and was also appointed in 1942 to the Chair of Ethnology then created. Marcel Cohen joined the Résistance (he was awarded the Croix de Guerre, 1939-45) but did not entirely stop his research work. He never returned to Ethiopia except for a few days in 1964 when he went there to obtain from the Emperor's hands the first Haile Sellassie Award for Ethiopian Studies ever granted. He was never appointed to the Collège de France, where he was several times a candidate for a Chair of Comparative Hamito-Semitic, nor did he occupy a Chair of Semitic Languages at the Sorbonne.

He was a member of many learned societies to which he devoted much of his time. He was also granted honorary degrees by several universities, among them the University of Manchester (1963).

Marcel Cohen was a man of exceptional physical and psychological resistance. In the last few years of his life his eyesight was bad and he gradually became 
almost blind. Nevertheless he preserved his self-discipline and continued working with the help of young assistants till the end. His wife Marguerite was his main help in all the work he did and his main support for more than 60 years. Though he suffered very much during the last years of his life and was tired of life, he awaited his death with much dignity. As he offered his body to medical research, there was no funeral.

He survives in his students and in the students of his students. He survives in his work. ${ }^{3}$ Opera illorum sequuntur illos.

3 For the bibliography see: Marcel Cohen, Cinquante années de recherches linguistiques, ethnographiques, sociologiques, critiques et pédagogiques, Paris, Klincksieck, 1955; David Cohen (ed.), Mélanges Marcel Cohen, Mouton, 1970, pp. xix-xxxix; Marcel Cohen, Bibliographie (1955-1973), [Paris, 1974], 26 pp. (mimeographed). 